\section{SIMULATION AND SENSITIVITY ANALYSIS ON THE PARAMETER OF NON-TARGETED IRRADIATION EFFECTS MODEL}

\author{
Muhamad Hanis Nasir, Fuaada Mohd Siam*
}

Department of Mathematical Sciences, Faculty of Science, Universiti Teknologi Malaysia, 81310 UTM Johor Bahru, Johor, Malaysia
Article history

Received

29 January 2018

Received in revised form

3 October 2018

Accepted

1 September 2018

Published online

15 December 2018

*Corresponding author fuaada@utm.my

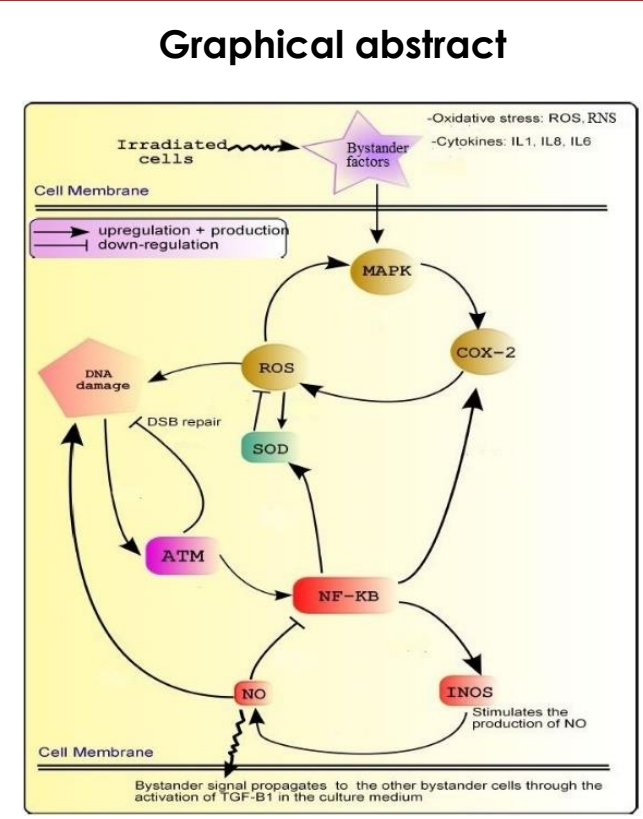

\begin{abstract}
Real-life situations showed damage effects on non-targeted cells located in the vicinity of an irradiation region, due to danger signal molecules released by the targeted cells. This effect is widely known as radiation-induced bystander effects (RIBE). The purpose of this paper is to model the interaction of non-targeted cells towards bystander factors released by the irradiated cells by using a system of structured ordinary differential equations. The mathematical model and its simulations are presented in this paper. In the model, the cells are grouped based on the number of double-strand breaks (DSBs) and mis-repair DSBs because the DSBs are formed in non-targeted cells. After performing the model's simulations, the analysis continued with sensitivity analysis. Sensitivity analysis will determine which parameter in the model is the most sensitive to the survival fraction of non-targeted cells. The proposed mathematical model can explain the survival fraction of nontargeted cells affected by the bystander factors.
\end{abstract}

Keywords: Bystander effects, double-strand breaks, survival fraction, sensitivity analysis, structured ordinary differential equation

\begin{abstract}
Abstrak
Keadaan situasi sebenar telah menunjukkan kesan-kesan kerosakan ke atas sel-sel bukan sasaran yang terletak berhampiran kawasan proses radiasi, disebabkan oleh molekul-molekul merbahaya yang dilepaskan oleh sel-sel sasaran. Kesan ini telah luas diketahui sebagai kesan sampingan disebabkan oleh radiasi (RIBE). Tujuan kertas kerja ini adalah untuk memodelkan interaksi oleh sel-sel bukan sasaran terhadap faktor molekul yang dilepaskan oleh selsel teradiasi dengan menggunakan sistem persamaan-persamaan perbezaan biasa yang berstruktur. Model matematik tersebut dan simulasinya dibentangkan di dalam kertas kerja ini. Dalam model tersebut, sel-sel dikumpulankan mengikut bilangan kepatahan dua-belah (DSBs) dan tersalah-pembaikan DSBs kerana DSBs terbentuk pada sel-sel bukan sasaran. Selepas melaksanakan simulasi model, analisis diteruskan dengan analisis kepekaan. Analisis kepekaan akan menentukan parameter mana di dalam model yang paling sensitif terhadap pecahan sel-sel bukan sasaran yang hidup. Model matematik yang dicadangkan boleh menerangkan pecahan hidup sel-sel bukan sasaran yang terjejas dengan faktor-faktor molekul merbahaya.
\end{abstract}

Kata kunci: Kesan-kesan berhampiran, kepatahan dua-belah, pecahan hidup, analisis kepekaan, persamaan perbezaan biasa berstruktur

(c) 2019 Penerbit UTM Press. All rights reserved 


\subsection{INTRODUCTION}

RIBE is a phenomenon observed in the non-targeted cells that are not directly traversed by irradiation [1,2]. This phenomenon had been examined experimentally by many researchers for over more than two decades. This phenomenon happened when the irradiated cells produced damaging signal molecules (bystander factors) to non-targeted cells that are not traversed by irradiation $[3,4,5,6,7]$, see Figure 1 . The candidates of bystander factors may include reactive oxygen species (ROS), interleukin-8, nitric oxide (NO), interleukin-1, reactive nitrogen species (RNS) and interleukin-6 $[4,7,8,9]$.

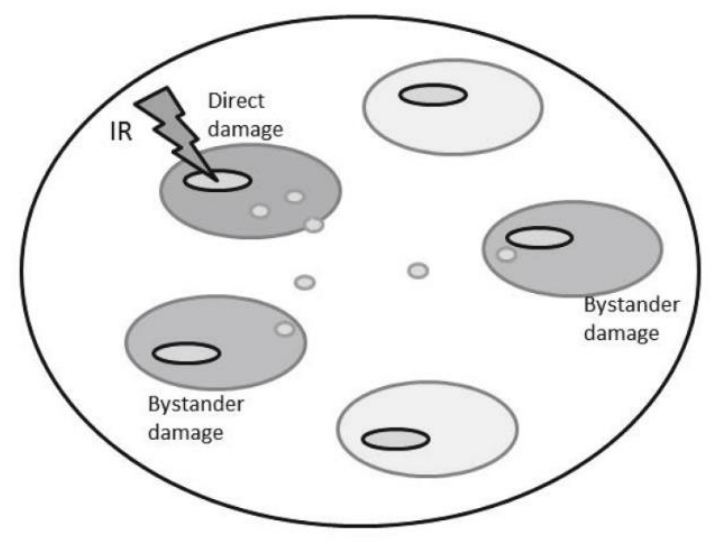

Figure 1 Basic mechanisms of RIBE [10]

The cellular reaction of bystander factors to nontargeted cells is a complex process. Here is the discussion on possible mechanism of cellular reaction in the non-targeted cells (see Figure 2).

The establishment of bystander response starts when mitogen-activated protein kinase (MAPK) family (such as extracellular signal-regulated kinases (ERK) and $\mathrm{c}$-Jun $\mathrm{N}$-terminal Kinase) receive some bystander factors mediated by soluble signaling molecules produced by the targeted cells. The activation of MAPK upregulates the expression of cyclooxygenase-2 (COX-2), thus leading to a significant increase of ROS. ROS also can activate back the MAPK. The ERK activation is an important upstream event which leads to COX-2 expression. This can be demonstrated by using the ERK inhibitor (PD 98059) and COX-2 inhibitor (NS-398). The closed loop between MAPK, COX-2 and ROS is a negative feedback loop, as a structure called a vicious circle [11].

Raised level of ROS leads to upregulation of superoxide dismutase (SOD), an antioxidant enzyme. Thus, a sufficiently high expression of SOD will reduce the level of ROS and break the vicious circle. At the same time, a high level of ROS initiates another negative feedback loop by producing DSBs. The DSBs will quickly activate ataxia-telangiectasia mutated kinase (ATM). The positive feedback loop between DNA damage and ATM can reduce the intensity of DNA damage due to the DNA damage repair processes. This consequently will decrease the level of activated ATM [12].

A phosphorylated ATM can also activate its downstream effectors such as nuclear factor- $\kappa \mathrm{B}(\mathrm{NF}-\kappa \mathrm{B})$ or phosphoprotein p53. However, ATM and p53 pathway is not important in modulating bystander responses. It is demonstrated that by using p53-independent cells, the bystander effects are observed in the cells even though p53 downstream is blocked [13]. The ATM and $N F-\kappa B$ is likely one of the most critical pathway in regulating bystander response. The NF- $\kappa$ B initiates a positive feedback mechanism by inducing the production of SOD. At the same time, NF- $\kappa \mathrm{B}$ upregulates COX-2 and activates the inducible nitric oxide synthase (iNOS) and NO pathway. The upregulation of iNOS by $N F-\kappa B$ stimulates the production of $\mathrm{NO}$ which leads to NF- $\kappa \mathrm{B}$ inhibition. NO also plays an important role in DSBs formation, thus contributing to the ATM and NF- $\kappa$ B pathway as part of the mechanism.

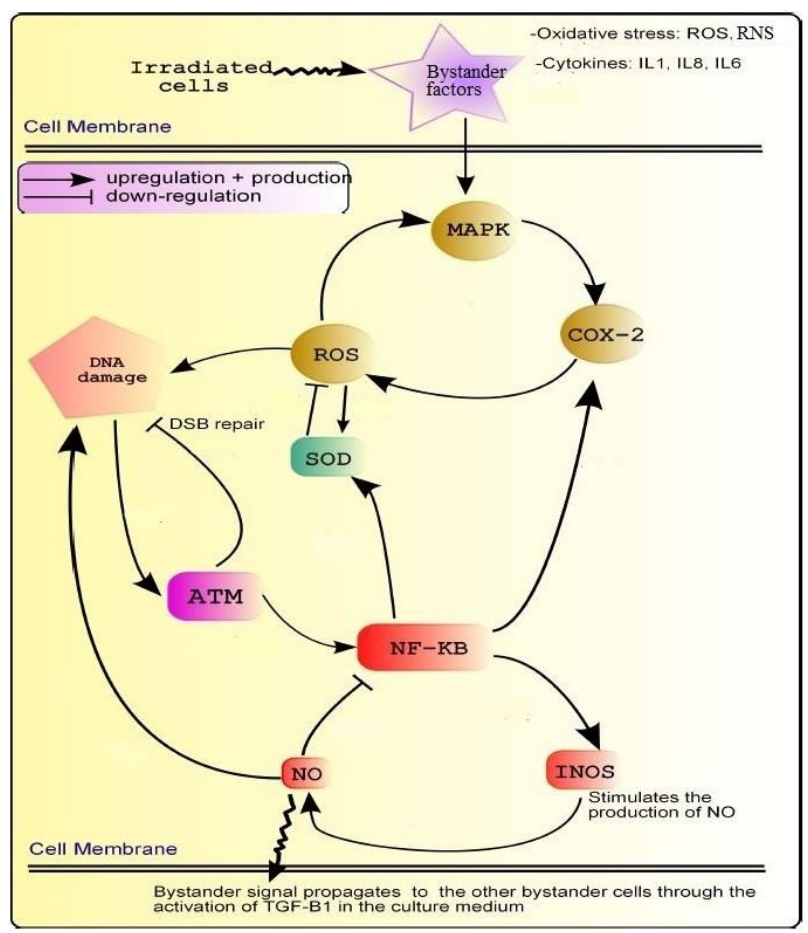

Figure 2 Cellular reaction in non-targeted cells [1 1]

In the experimental works, Sokolov et al. [14] showed that there is induction of $\gamma-\mathrm{H} 2 \mathrm{AX}$ foci in the non-targeted cells after irradiation process. The $y^{-} \mathrm{H} 2 \mathrm{AX}$ foci is a phosphorylated form of histone H2AX which are early induced after the formation of DSBs and it is an important response towards DNA damage. Some researchers $[4,7,15]$ agreed that $\mathrm{z}-\mathrm{H} 2 \mathrm{AX}$ foci formation is acted as a biomarker of DSBs. The same evidence reported by $\mathrm{Hu}$ et al. [16], after $\alpha$-particle traversed $1 / 10$ of the cells nuclei, there is excessive $y^{-H} 2 \mathrm{AX}$ immunofluorescence observed in the non-targeted cells. Wang et al. [4] mentioned that each discrete $\gamma^{-}$ H2AX foci contain a single DNA DSBs damage and the 
number of DSBs can be measured by counting the number of $\gamma^{-} \mathrm{H} 2 \mathrm{AX}$ foci in the cell's nucleus.

The DNA DSBs damage usually considered as the crucial initial damage [6], which latter produce subsequent insidious damage effects such as chromosomal aberration, sister chromatid exchanges, unrepaired and mis-repaired DNA lesions. Induction of DNA DSBs damage will be followed by the repair process, which is homologous recombination repair and non-homologous end joining repair. Interested reader can refer to $[17,18]$ for more details about the repair process. Although cells have two complex repair mechanisms for dealing with DSBs, some of the damages are not repaired or are mis-repaired [19].

Recently, Siam et al. [20] developed a modelling framework of repair--mis-repair DNA DSBs damage on targeted effects of irradiation. It is interesting to study the non-targeted effects of irradiation since it is proven experimentally that there are cell death to nontargeted cells following irradiation. This paper focused on simulation of the model of non-targeted irradiation effects with different value of parameter and its sensitivity analysis. The sensitivity analysis helps to determine which parameter in the model that has strong effects to the model output. Hence, this parameter will be given more focus in the therapeutic procedure for protecting the non-targeted cells from death due to irradiation effects.

\subsection{METHODOLOGY}

\subsection{Modelling of Non-targeted Irradiation Effects}

Following the biological effects discussed in previous section, the DNA DSBs damage is formed in the nontargeted cells by measuring $y-H 2 A X$ foci formation, a direct biomarker of DSBs. The assumption suggested by Hattori et al. [21], stated that the number of DSBS formed after being in contact with bystander factors is proportional to the quantities of bystander factors. Thus, the probability of a non-targeted cell acquiring $k$ DSBs follows the Poisson distribution with mean:

$$
\mu=\vartheta C
$$

where $\vartheta$ is the DSBs induction coefficient among the non-targeted cells, which is also refers as the sensitivity of non-targeted cells towards bystander factors and $C$ is the bystander factors.

The model of bystander factors to be used is taken from Kundrát and Friedland [22]. The model is as follows:

$$
C=1-\exp \left\{-\mathrm{D} / D_{C}\right\}
$$

where $C$ is the relative concentration emitted into the medium by the irradiated cells irradiated with dose $D$ and $D_{c}$ is the value of characteristic sensitivity of the irradiated cells.
By using Poisson distribution function, the probability of one non-targeted cell acquiring $k>0$ DSBs after react with bystander factor is given by:

$$
P(\mathrm{DSBs}=k)=\frac{\mu^{k} e^{-\mu}}{k !} .
$$

After the DSBs have been generated in each nontargeted cell, the model of repair and mis-repair DNA DSBs suggested by siam et al. [20] is taken into consideration for investigating the dynamical process of a population of non-targeted cells. The variable $N_{k, m}$ refers to a group of non-targeted cells that having $k$ DSBs and $m$ mis-repair DSBs. The model is as follows:

$$
\begin{aligned}
\frac{d N_{k, m}}{d t}=- & \beta(k, m) N_{k, m}-\gamma(k) N_{k, m} \\
& +p \gamma(k+1) N_{k+1, m} \\
& +(1-p) \gamma(k+1) N_{k+1, m-1},
\end{aligned}
$$

for $k=0,1,2, \ldots, k_{\max } m=0,1,2, \ldots, k_{\max }$ with $k+m \leq$ $k_{\max }$ and $k_{\max }$ is the maximum number of DSBs in a population of non-targeted cells. The parameter $\beta, \gamma$ and $p$ are the death rate, the repair rate and the probability of successful repair of 1 DSB, respectively.

The death rate, $\beta$ of a cell died is considered in two ways, that is due to mis-repair of DSBs and the interaction of two DSBs located in spatial proximity formed a lethal chromosomal aberration. Hence, the death rate is presented as:

$$
\beta(k, m)=\alpha_{1} m+\alpha_{2} k^{2},
$$

where $\alpha_{1}$ is a mis-repair death rate constant while $\alpha_{2}$ is a lethal damage rate constant. The Equation (5) is employed from Siam et al. [20] model by considering that the DNA DSBs damage is formed in non-targeted cells. When the number of DSBs is high, there is more chance of mis-repair the DSBs and lethal chromosomal aberrations formation.

The repair rate, $y$ is the rate of DSB repair for a group of non-targeted cells having $k$ DSBs. The repair process is described by Michaelis-Menten kinetics equation:

$$
\gamma(k)=\frac{V_{\max } k}{K_{M}+k},
$$

where $k=0,1,2, \ldots$ is the number of DSBs, $V_{\text {max }}$ is the maximum repair rate and $K_{M}$ is the Michaelis-Menten constant; a constant number at which the maximum repair rate is halved.

Another critical effect of bystander phenomenon is DNA repair delays $[23,24]$. In the present model, the repair delay effect is captured by using a Heaviside step function. The Heaviside step function defined as follows: 


$$
h(t)= \begin{cases}0 & \text { if } t \leq \tau, \\ 1 & \text { if } t>\tau\end{cases}
$$

where $\tau$ is the time of delay before the repair process begin. Therefore, in this work, the repair rate with DNA repair delay can be rewritten as:

$$
\gamma(k, h)=\frac{V_{\max } k h}{K_{M}+k} .
$$

The repair rate function will be activated depends on the duration of delay. Therefore, the model of DNA DSBs damage with delay activation of repair process is written as:

$$
\begin{aligned}
\frac{d N_{k, m}}{d t}= & -\beta(k, m) N_{k, m}-\gamma(k, h) N_{k, m} \\
& +p \gamma(k+1, h) N_{k+1, m} \\
& +(1-p) \gamma(k+1, h) N_{k+1, m-1} .
\end{aligned}
$$

In the simulation, the Poisson distribution in Equation (3) will randomly generates the value of $k_{\text {max }}$. The variable $N_{k, m}$ that will exist in a population of nontargeted cells depends on $k_{\max }$. If $k_{\max }=1$, there are 3 variables: $N_{0,0}, N_{1,0}$ and $N_{0,1}$. If $k_{\max }=2$, there are 6 variables: $N_{0,0}, N_{1,0}, N_{2,0}, N_{0,1}, N_{1,1}$ and $N_{0,2}$. If $k_{\max }=3$, there are 15 variables: $N_{0,0}, N_{1,0}, N_{2,0}, N_{3,0}, N_{0,1}, N_{1,1}, N_{2,1}$, $N_{0,2}, N_{1,2}$ and $N_{0,3}$. In general, if the maximum number of DSBs in a population of non-targeted cells is $k_{\text {max }}$, the number of variable exist in vector $\mathbf{N}$ is $M$ and dimension of matrix $\mathbf{A}$ is $M \times M$ with:

$$
M=\frac{\left(k_{\max }+1\right)\left(k_{\max }+2\right)}{2} .
$$

Lastly, with any number of $k_{\max }$, the model (9) takes form of derivative:

$$
\frac{d \mathbf{N}}{d t}=\mathbf{A} \mathbf{N},
$$

where $\mathbf{N}$ is a matrix that representing all the variables, $N_{k, m}$ and $\mathbf{A}$ is the coefficient matrix. According to [25], the solution for this type of initial value problem is as follows:

$$
\mathbf{N}(t)=e^{\mathbf{A}\left(t-t_{0}\right)} \mathbf{N}_{0},
$$

where $\mathbf{N}_{0}$ is the vector of initial condition at time $t=t 0$. The initial distribution only generate the number of DSBs $(k)$, therefore set $N_{k, m}(0)=0$ for $m>0$ for each value of $k$.

The solution, $\mathbf{N}(t)$ can be solved at any time $t$. However, $\mathbf{N}(t)$ is not the final solution sought. The total survival fraction of cells for the solution $\mathbf{N}(t)$ is given as:

$$
\mathrm{SF}=\frac{\sum_{m=0}^{k_{\max }-k} \sum_{k=0}^{k_{\max }} N_{k, m}(t)}{\sum_{m=0}^{k_{\max }-k} \sum_{k=0}^{k_{\max }} N_{k, m}(0)}
$$

Where SF is the survival fraction of non-targeted cells at time, $t$.

\subsection{Sensitivity Analysis}

Sensitivity analysis is a method to investigate the model behaviour and its response to changes of model inputs. There are many sensitivity analysis methods have been developed and suitable for any mathematical models, as reviewed in [26]. The model is regarded as a mapping between the model inputs and the model outputs. For simplicity, the sensitivity analysis method that is used in this work is differentiation-based methods, which is also refers as the elasticity of models output with respect to models parameter [26].

To do this analysis, a small perturbation to the parameter of the model is carried out. The outcome of sensitivity analysis approach can be chosen depends on the objectives need to be fulfilled. Let say that there are $n$ model inputs and $m$ model outputs, such that $\mathbf{x}=$ $\left[x_{1}, x_{2}, \ldots, x_{n}\right]$ and $\mathbf{y}=\left[y_{1}, y_{2}, \ldots, y_{n}\right]$. Formally, it is written as:

$$
\mathbf{y}=f(\mathbf{x}),
$$

where $f: \zeta \rightarrow \xi$ with $\zeta \subseteq \mathbb{R}^{n}$ and $\xi \subseteq \mathbb{R}^{m}$. $\zeta$ is the model input space and $\xi$ is the model output space [26]. The model output can be predefined in term of steady state response, maximum response or time-dependent response [27]. In this work, the model output is defined in term of dose-dependent response (carried out in Section 3.2).

Previously, to study the reliability of the mitogenactivated protein kinase cascade model, the hepatitis $C$ viral dynamics model and the response surface methodology and two phase mixture model, the researchers considered the sensitivity analysis approach in their work [27, 28, 29]. There are two types of sensitivity analysis, that is local sensitivity analysis (LSA) and global sensitivity analysis (GSA). LSA is a study of the changes in the model outputs with respect to single parameter variation and the other parameters are fixed, while GSA is a study of changes in the model outputs by perturbing all the parameters simultaneously [27].

Mathematically, the sensitivity coefficients are the first order derivatives of a model output with respect to the model parameter [27], which is defined as follows:

$$
S_{i, j}^{\text {unscaled }}=\frac{\partial O_{i}}{\partial p_{j}},
$$

where $O_{i}$ is the $i$-th model output and $p_{j}$ is the $j$-th parameter. $S_{i, j}$ unscaled is called unscaled or 
unnormalized sensitivity coefficient. In [30], the derivative in Equation (15) is approximated by using forward difference approximation as follows:

$$
\frac{\partial O_{i}}{\partial p_{j}} \approx \frac{O_{i}\left(p_{j}+\Delta p\right)-O_{i}\left(p_{j}\right)}{\Delta p}
$$

where $\Delta p$ is the value of changes of $p_{j}$ and $O_{i}$ is the model output at $p_{j}$ and $p_{j}+\Delta p$, respectively. If $1 \%$ perturbation is applied to the parameter, then $\Delta p=$ $0.01 \times p_{j}$. The value of percentage perturbation should normally chosen less than a $5 \%$ deviation from parameter, $p_{j}[30]$.

The scaled or normalized sensitivity coefficients is defined as follows:

$$
S_{i, j}^{\text {scaled }}=\frac{\partial O_{i}}{\partial p_{j}} \times \frac{p_{j}}{O_{i}}
$$

or

$$
S_{i, j}^{\text {scaled }} \approx \frac{O_{i}\left(p_{j}+\Delta p\right)-O_{i}\left(p_{j}\right)}{\Delta p} \times \frac{p_{j}}{O_{i}}
$$

$S_{i, j}$ scaled can be interpreted as the percentage changes in $O_{i}$ for each percentage change in $p_{j}$ and it is frequently used to describe precisely the model's behaviour. The value of $S_{i, j}$ scaled can be positive or negative, which indicates whether the parameter, $\mathrm{p}_{j}$ increases or decreases the model's outputs, $O_{i}$ [24].

\subsection{RESULTS AND DISCUSSION}

\subsection{Simulation of the Model}

The value of parameter used for the simulation are: $\vartheta=$ $6 C^{-1}, D_{C}=1.2 \mathrm{~Gy}, \alpha_{1}=0.05 h^{-1}, \alpha_{2}=0.002 h^{-1}, p=0.9$, $V_{\max }=2 h^{-1}, K_{M}=4$ and $\tau=0.5$. See Figure 3 for the simulation graph.

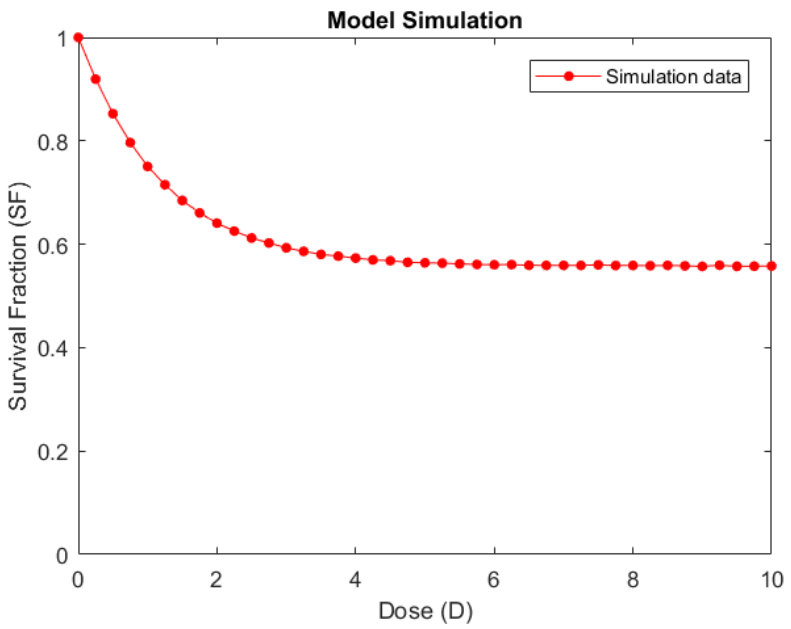

Figure 3 The model simulation at time, $t=24$ hours
In each irradiation dose (D), the model discussed in Section 2.1 is solved at time, $t=24 \mathrm{~h}$. The time $t=24 \mathrm{~h}$ is chosen due to the fact that a cell cycle by human cells will divide into two daughter cells approximately every 24 hours [31]. For a typical rapidly proliferating human cell with a total cycle time of 24 hours, the $G_{1}$ phase might last about 11 hours, $S$ phase about 8 hours, $G_{2}$ about 4 hours and $M$ about 1 hour [31]. The repopulation is not discussed in the model and no term in the model that discussed on the cell division after complete a cell cycle phases. Thus, solving the model for more than 24 hours is not valid for the model.

Each parameter $\left(\vartheta, D_{c}, \alpha_{1}, \alpha_{2}, p, V_{\max }, K_{M}\right.$ and $\left.\tau\right)$ will be varied in order to analyze the behaviour of the model's simulation, as shown in Figure 4: $(\mathrm{A})-(\mathrm{H})$.

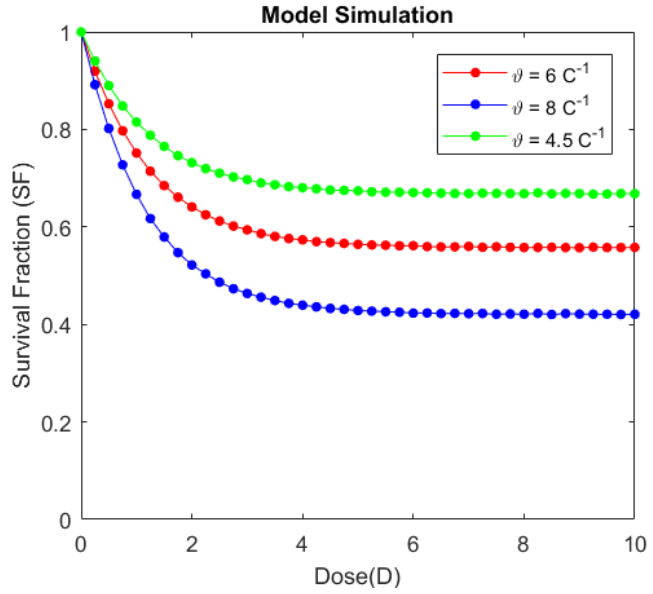

(A) Parameter $\vartheta$.

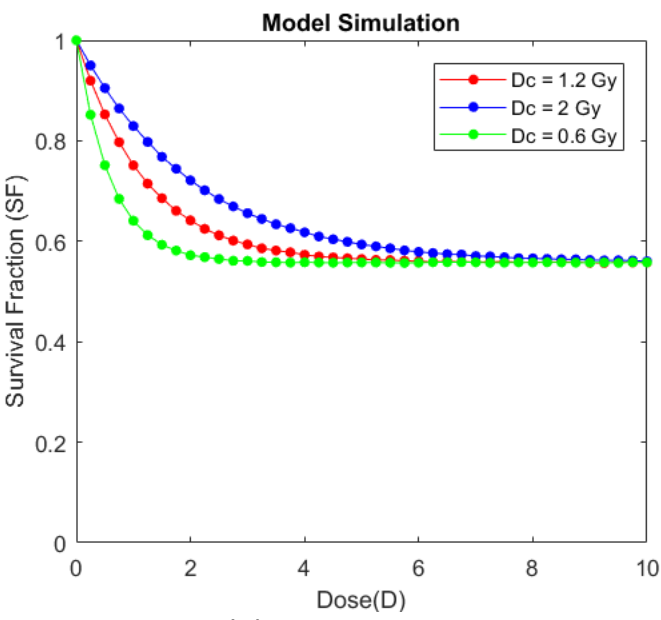

(B) Parameter DC. 


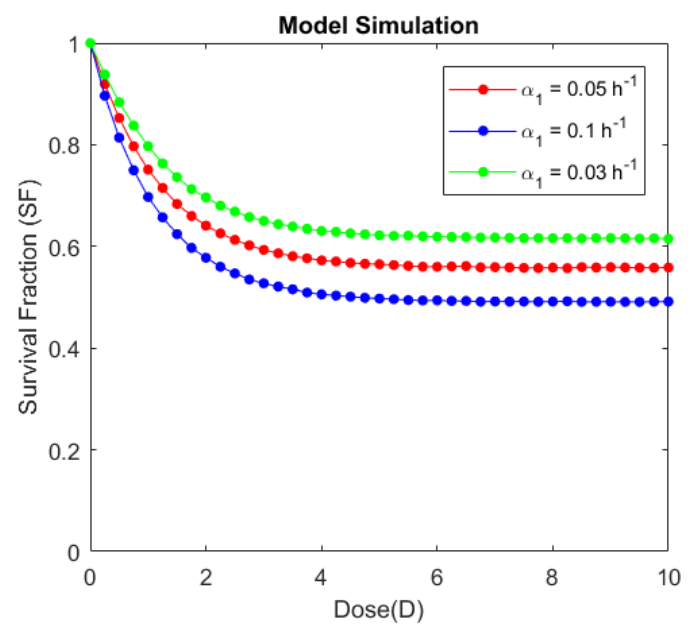

(C) Parameter $\alpha_{1}$.

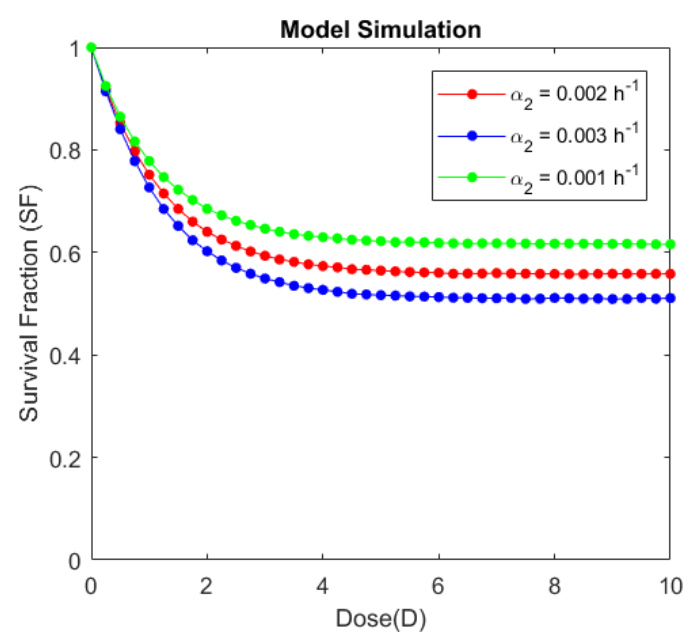

(D) Parameter $\alpha 2$.

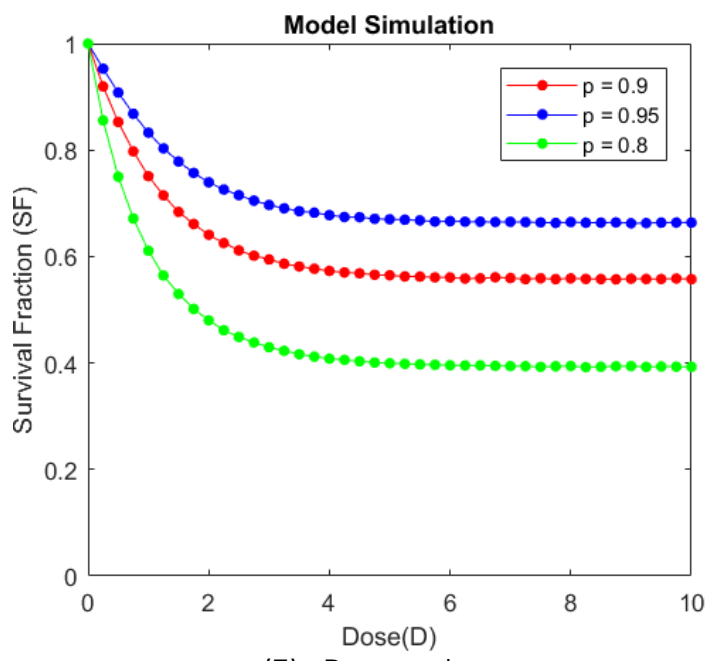

(E) Parameter p.

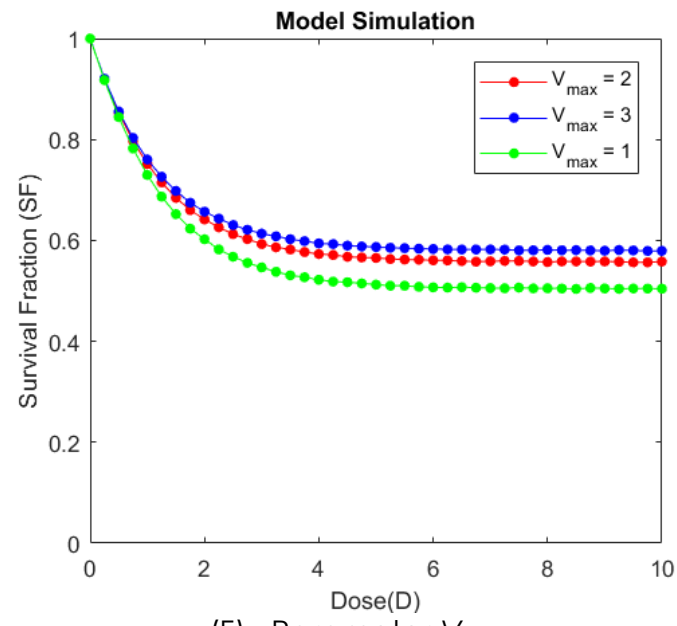

(F) Parameter $V_{\text {max. }}$.

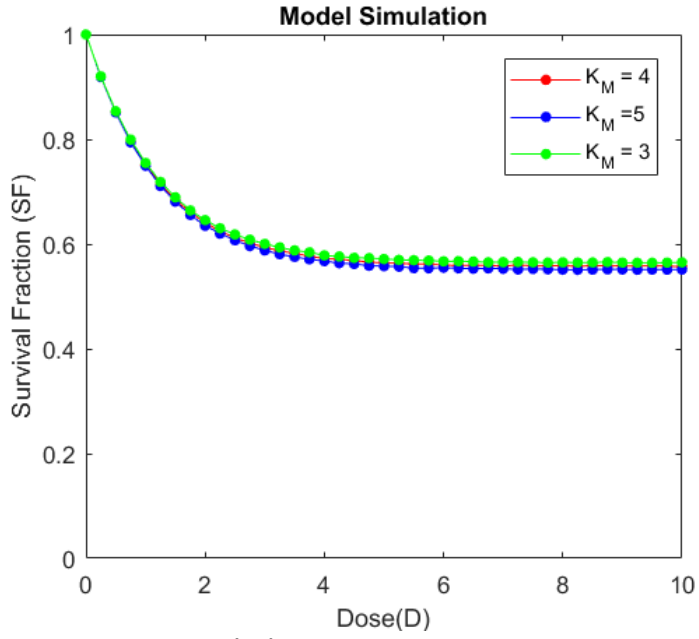

(G) Parameter $K_{M}$.

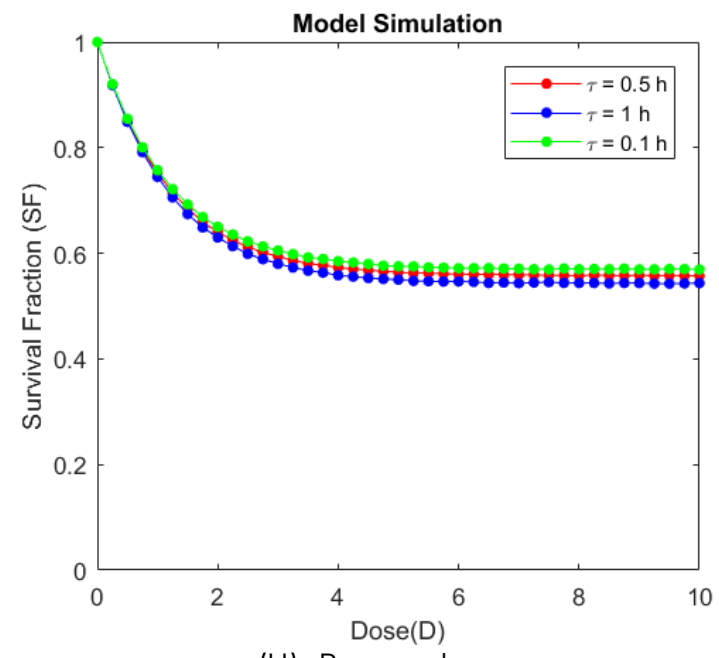

(H) Parameter $\tau$.

Figure $4(A)-(H)$ : Simulation of each parameter with varying value 
From the simulation results of each parameter as shown Figure 4, there can be seen that the increasing value of parameter $\vartheta, \tau, \alpha_{1}$ and $\alpha_{2}$ will decrease the survival of non-targeted cells. Parameter $\vartheta$ refers to sensitivity of non-targeted cells towards bystander factors, high sensitivity causes the non-targeted cells gain more DNA damages. Parameter $\tau$ refers to repair delays, a few time intervals before repair process begin, several nontargeted cells had going to death due to DNA damage. Parameters $\alpha_{1}$ and $\alpha_{2}$ are the parameters in death rate, thus increasing the value of $\alpha_{1}$ and $\alpha_{2}$ can increase the number of cell death.

On the other hand, higher value of parameters Dc, $p$ and $V_{\max }$ will increase the survival of nontargeted cells. Parameter $D_{c}$ is the sensitivity of the targeted cells to irradiation. High sensitivity of targeted cells cause the targeted cells immediately died after irradiation. According to Lintott et al. [10], the targeted cells produce and emit bystander signals. However, if the targeted cells go to death, the bystander factors emission will be ceased. Parameter $p$ is the probability of successful repair the DSBs damage and $V_{\text {max }}$ is the maximum repair rate of the non-targeted cells, therefore increasing the value of $p$ and $V_{\max }$ will increase the survival of nontargeted cells.

In future, the value of each parameter should be determined by using data fitting procedure with the experimental data, so that the simulation of the model could give meaningful information.

It is also possible to carry out the simulation of the survival fraction of non-targeted cells with respect to time, $t$. The idea to perform this simulation is by observing the dynamics of survival cells with respect to time at a fixed dose value. By using the same parameter values in previous simulation, the dynamics of survival non-targeted cells is observed at a fixed dose, D=0.5 Gy, 1 Gy, 2 Gy, 4 Gy and 8 Gy. Figure 5 shows the survival of 10000 initial number of non-targeted cells decreases over the time for up to 24 hours.

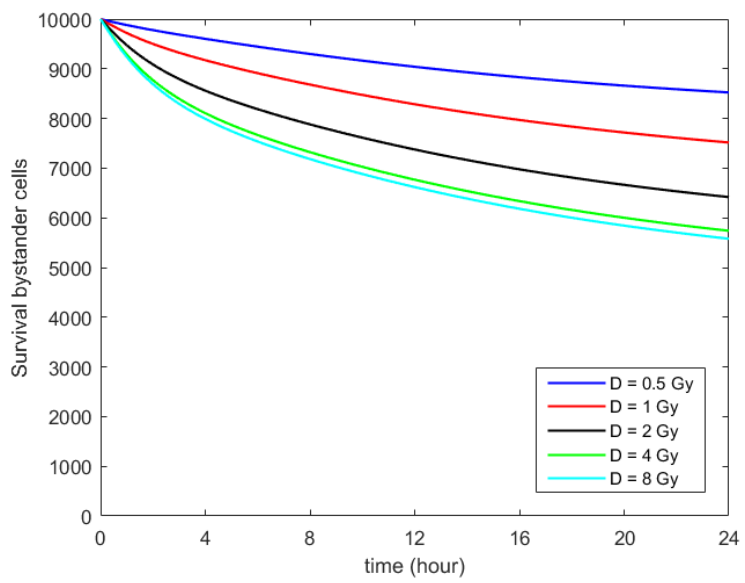

Figure 5 Survival cells versus time up to $25 \mathrm{~h}$
As shown in Figure 5, survival of non-targeted cells decreases over the time. The survival cells also act independently in each dose because the DSBS formation in non-targeted cells are not dependent on dose [32]. At higher doses, the amount of bystander factors released by the irradiated cells almost saturated to the highest level that could be produced. Thus, the survival of non-targeted cells at higher doses does not differ too much.

Figure 6 shows the survival non-targeted cells when $t$ increases. When the time increases, the dynamic of survival non-targeted is not further decreasing because it reaches a state of there is no DSBs in the non-targeted cells population.

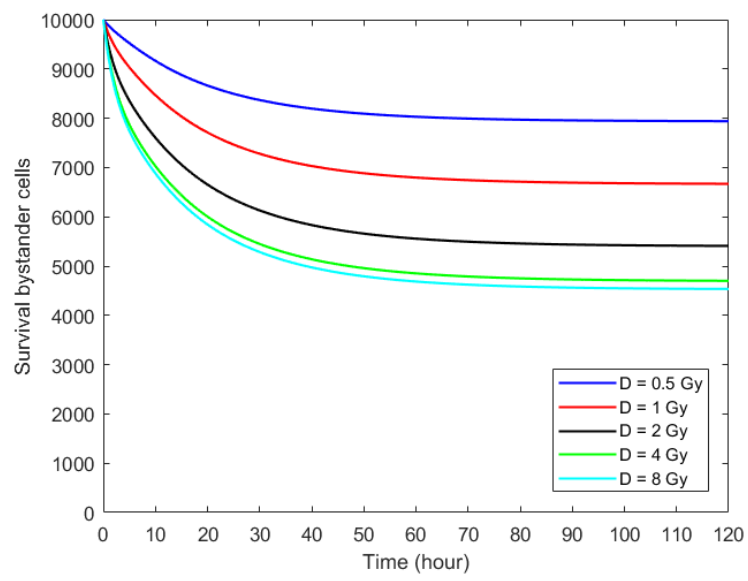

Figure 6 Survival bystander cells versus time for up to $120 \mathrm{~h}$ (5 days)

However, solving the model for more than $24 \mathrm{~h}$ is not valid for the current model because one complete cell cycle is approximately $24 h$ [31]. After $24 \mathrm{~h}$, the non-targeted cells that already repaired all the DSBs will tend to have possibility to divide into two daughter cells. The current model did not discussed on the cell division term and it will be referred to future work.

\subsection{Sensitivity of Model Parameter}

In this work, the survival fraction (SF) of non-targeted cells is regarded as the model's output. Response sensitivity of SF is determined from the beginning of the DSBs formation on a population of non-targeted cells until to the end of the simulation time (24 hours). The scaled sensitivity coefficient for SF is defined as:

$$
S_{j}^{\text {scaled }}=\frac{\partial(\mathrm{SF})}{\partial p_{j}} \times \frac{p_{j}}{\mathrm{SF}}
$$

for $j=1$ to 8 since the model has 8 parameters: $p_{j}=\{\vartheta$, $\left.D_{c}, \alpha_{1}, \alpha_{2}, p, V_{\text {max }}, K_{M}, \tau\right\}$.

The scaled sensitivity coefficient are determined by model simulation. According to Equation (18), Equation (19) is rewritten as: 


$$
S_{j}^{\text {scaled }} \approx \frac{\mathrm{SF}\left(p_{j}+\Delta p\right)-\mathrm{SF}\left(p_{j}\right)}{\Delta p} \times \frac{p_{j}}{\mathrm{SF}\left(p_{j}\right)},
$$

where $\operatorname{SF}\left(p_{j}\right)$ and $\operatorname{SF}\left(p_{j}+\Delta p\right)$ is the simulation of the model at $p_{j}$ and $p_{j}+\Delta p$, respectively. In this work, $1 \%$ deviation is chosen, then $\Delta p=0.01 \times p_{j}$.

The blue, white and red colour are used to differentiate the difference between increasing and decreasing values of SF (as shown in Figure 7).

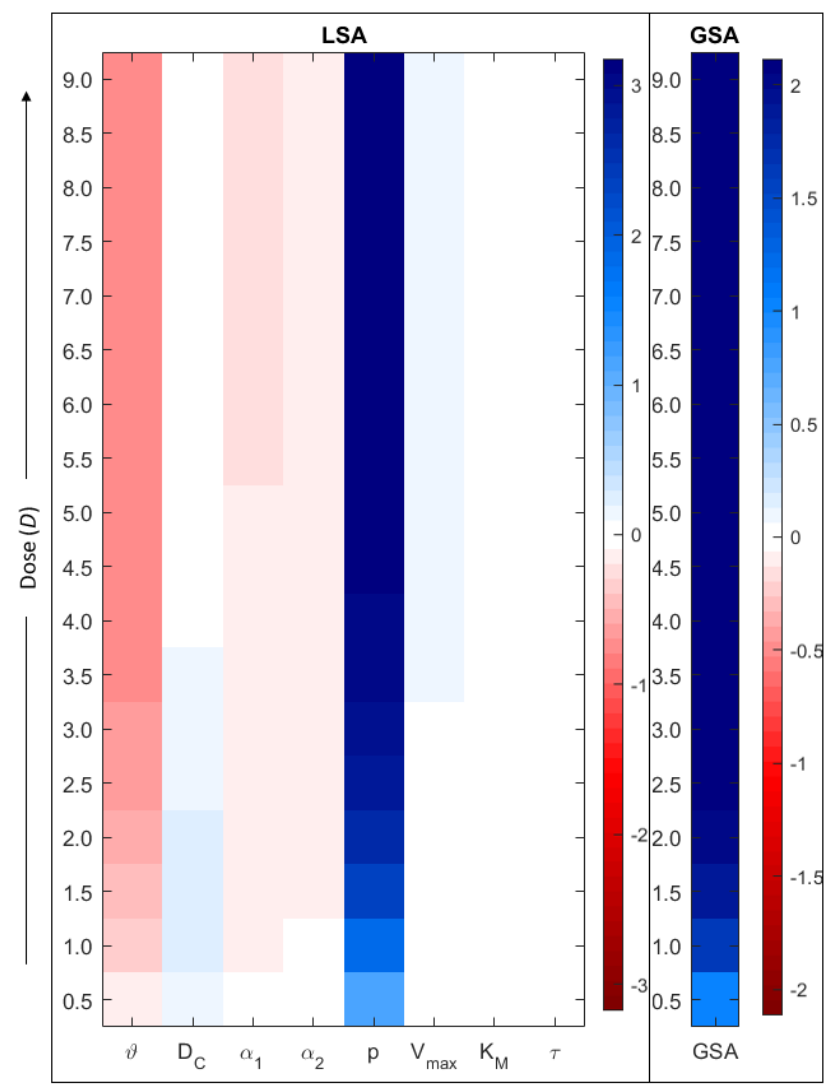

(A)

(B)

Figure 7 Sensitivity coefficient graph. The colour scale on the right of each graph represents the percentage value, either increasing or decreasing

For LSA, as shown in Figure 7(A), the parameters can be divided into three groups: positive response, negative response and almost no response to the changes of SF. The positive group has $D_{c}, p$ and $V_{\text {max }}$, the negative group has $\vartheta_{1} \alpha_{1}$ and $\alpha_{2}$ and the rest belongs to almost no change group. The positive group of the parameter increases the SF of nontargeted cells, while the negative group decreases the SF. For GSA, as shown in Figure $7(B)$, increasing $1 \%$ perturbation of all parameters simultaneously cause an increase value of SF.

Through these analyses, suggestion can be pointed out for increasing the cell survival of nontargeted cells. The parameter $\vartheta$ can be decreased by protecting the non-targeted cells. Radioprotectors are the agents needed to protect the biological mechanism exposed to irradiation, also protecting non-targeted cells from irradiation injury in a cancer patient whose undergoes the radiotherapy [31]. The non-targeted cells communicate with nearby targeted cells through gap junctions. Thus, targeting gap junctions and their protein such as connexins may significantly reduce the bystander response. For example, lindane ( $z$ hexachlorocyclohexane) forbids gap junction formation between cells by endocytotic mechanism [33].

In the bystander factors model Equation (2), the relative concentration released is increasing with respect to dose. Among the various type of bystander factors, there are two types of small molecules have given considerable attention due to the capability of traversing the medium to nontargeted cells, that is ROS (e.g.: hydrogen peroxide and lipid peroxides) and RNS (e.g.: NO, dinitrogen trioxide and peroxynitrite) [34]. ROS is a category of free radical containing oxygen while RNS contains nitrogen. The survival non-targeted cells can be increased by treatment with ROS scavengers such as dimethyl sulfoxide or NO inhibitors such as C-PTIO, which is effectively reduced the DSB formation [35].

The parameter $p$ and $V_{\max }$ are related to each other in terms of DNA repair. Both parameters can be increased by heightening the DNA repair mechanism and activating more cellular DNA repair pathways. For example, DNA repair can be enhanced using nicotinamide, glutathione monoester and amifostine [36]. Amifostine or WR-2721 protects non-targeted cells by suppressing free radicals and quickening the recovery of damaged DNA by giving hydrogen.

Other than clinical product, there are many natural sources that can be used as the radioprotectors against free radicals. Free radicals are molecules that having an unpaired electron, and they steal electron from other molecules such as fats, proteins and DNA. This process is called oxidation and it sets off a chain of reaction by damaging cell's DNA. Antioxidants like melatonin, tempace, vitamin $A, C$ and $E$ are able to block the propagation of chain reactions initiated by free radicals [31]. Antioxidants can stop the free radical damage to molecules by receiving or giving an electron to make it stable. Antioxidants remain stable when they donate or accept an electron.

Parameter $\alpha_{1}$ and $\alpha_{2}$ are death rates, especially $\alpha_{2}$ refers the cell death caused by lethal formation of chromosomal aberration. Therefore, both parameter can be decreased by treatment with an antioxidant like vitamin $C$, which is able to inhibit and reduce the frequency of chromosomal aberrations formation [36]. Also, the cell death can be reduced by inhibiting the death signaling pathways. The cell death can occur due to the activation of p53 signaling and apoptotic pathways. Thus, an agent that functions as p53 inhibitor can block the apoptotic pathway and prevent cell death. 


\subsection{CONCLUSION}

A mechanistic model is proposed to describe the irradiation effects to non-targeted cells. The simulations of the model indicate that the survival of non-targeted cells did not follow dose dependency. The result on the elasticity analysis of the model illustrates that the major control response to the survival fraction of non-targeted cells is regulated by the DSBs induction coefficient among bystander cells, $\vartheta$ and successful repair probability of nontargeted cells, p. For further development, the mathematical model developed in this work should be continued with parameter fitting procedure. Parameter fitting procedure is a method which requires an experimental data in order to prove the accuracy of a mathematical model [37]. It also can be suggested that the bystander factors concentration released by the targeted cells into the medium follow a saturating Michaelis-Menten saturating function so that, the possible value of maximum signal concentration released could be analyzed.

\section{Acknowledgement}

This work was financially supported by the Universiti Teknologi Malaysia under the Fundamental Research Grant Scheme (FRGS: R.J130000.7826.4F889) and Ministry of Education Malaysia (MOE). The first author would like to thank MOE for his MyBrainSc Scholarship.

\section{References}

[1] Mothersill, C., Fernandez-Palomo, C., Fazzari, J., Smith, R. Schültke, E., Bräuer-Krisch, E., Laissue, J., Schroll, C. and Seymour, C. 2014. Transmission of Signals from Rats Receiving High Doses of Microbeam Radiation to Cage Mates: An Inter-Mammal Bystander Effect. DoseResponse. 12(1): 72-92.

DOI: $\quad$ http://dx.doi.org/10.2203\%2Fdose-response.13011 .Mothersill.

[2] Nasir, M. H. and Siam, F. M. 2017. Mini-review: Recent Updates on the Mathematical Modelling of Radiationinduced Bystander Effects. Malaysian Journal of Fundamental and Applied Sciences. 13(2): 103-108. DOI: http://dx.doi.org/10.11113/mifas.v13n2.563.

[3] Lin, X., Wei, F., Major, P., Al-Nedawi, K., Al Saleh, H. A., and Tang, D. 2017. Microvesicles Contribute to the Bystander Effect of DNA Damage. International Journal of Molecular Sciences. 18(4): 788-800.

DOI: http://dx.doi.org/10.3390/ijms18040788.

[4] Wang, H., Yu, K. N., Hou, J., Liu, Q. and Han, W. 2015. Radiation-induced Bystander Effect: Early Process and Rapid Assessment. Cancer Letters. 356(1): 137-144. DOI: https://doi.org/10.1016/j.canlet.2013.09.031

[5] Najafi, M., Fardid, R., Hadadi, G. and Fardid, M., 2014. The Mechanisms of Radiation-induced Bystander Effect. Journal of Biomedical Physics \& Engineering. 4(4): 163-172.

[6] Nikitaki, Z., Mavragani, I.V., Laskaratou, D.A., Gika, V., Moskvin, V.P., Theofilatos, K., Vougas, K., Stewart, R.D. and Georgakilas, A.G., 2016, June. Systemic Mechanisms and Effects of Ionizing Radiation: A New "Old" Paradigm of
How the Bystanders and Distant Can Become the Players. Seminars in Cancer Biology. 37: 77-95. Academic Press. DOI: https://doi.org/10.1016/j.semcancer.2016.02.002

[7] Havaki, S., Kotsinas, A., Chronopoulos, E., Kletsas, D. Georgakilas, A., \& Gorgoulis, V. G. 2015. The Role of Oxidative DNA Damage in Radiation Induced Bystander Effect. Cancer Letters. 356(1): 43-51.

DOI: https://doi.org/10.1016/j.canlet.2014.01.023.

[8] Desouky, O., Ding, N. and Zhou, G. 2015. Targeted and Non-Targeted Effects of lonizing Radiation. Journal of Radiation Research and Applied Sciences. 8(2): 247-254. DOI: https://doi.org/10.1016/j.jrras.2015.03.003.

[9] Sprung, C. N., Ivashkevich, A., Forrester, H.B., Redon, C.E., Georgakilas, A. and Martin, O.A. 2015. Oxidative DNA Damage Caused by Inflammation May Link to Stressinduced Non-Targeted Effects. Cancer Letters. 356(1): 7281.

DOI: https://doi.org/10.1016/j.canlet.2013.09.008.

[10] Lintott, R., McMahon, S., Prise, K., Addie-Lagorio, C. and Shankland, C. 2014. Using Process Algebra to Model Radiation Induced Bystander Effects. International Conference on Computational Methods in Systems Biology. Springer, Cham. 196-210. DOI: https://doi.org/10.1007/978-3-319-12982-2_14.

[11] Siam, F.M. 2014. Modelling Effects of Ionising Radiation. Doctoral Dissertation. University of Strathclyde.

[12] F. M. Siam, M. Grinfeld. 2014. Modeling ATM DNA Damage Sensor Mechanism. Advances in Mathematics Modeling. Ed. Yusof Yaacob. Penerbit UTM Press. 15-36.

[13] Ivanov, V. N., Zhou, H., Ghandhi, S. A., Karasic, T. B. Yaghoubian, B., Amundson, S. A. and Hei, T. K. 2010. Radiation-induced Bystander Signaling Pathways in Human Fibroblasts: A Role for Interleukin-33 in the Signal Transmission. Cellular Signaling. 22(7):1076-1087. DOI: $\mathrm{https}: / /$ doi.org/10.1016/j.cellsig.2010.02.010

[14] Sokolov, M. V., Smilenov, L. B., Hall, E. J., Panyutin, I. G., Bonner, W. M. and Sedelnikova, O. A. 2005. Ionizing Radiation Induces DNA Double-Strand Breaks in Bystander Primary Human Fibroblasts. Oncogene. 24(49): 7257-7265. DOI: https://doi.org/10.1038/sj.onc.1208886.

[15] Sedelnikova, O. A., Nakamura, A., Kovalchuk, O., Koturbash, I., Mitchell, S. A., Marino, S. A., Brenner, D. J. and Bonner, W. M. 2007. DNA Double-strand Breaks Form in Bystander Cells after Microbeam Irradiation of Threedimensional Human Tissue Models. Cancer Research. 67(9): 4295-4302.

DOI: https://doi.org/10.1158/0008-5472.CAN-06-4442.

[16] Hu, B., Han, W., Wu, L., Feng, H., Liu, X., Zhang, L., Xu, A. Hei, T.K. and Yu, Z. 2005. In situ Visualization of DSBs to Assess the Extranuclear/Extracellular Effects Induced by Low-Dose $\alpha$-particle Irradiation. Radiation Research. 164(3): 286-291.

DOI: https://doi.org/10.1667/RR3415.1.

[17] Hall, E. J. and Giaccia, A. J. 2006. Radiobiology for the Radiologist. Lippincott Williams \& Wilkins.

[18] Stein, G. S. and Pardee, A. B. 2004. Cell Cycle and Growth Control: Biomolecular Regulation and Cancer. John Wiley \& Sons.

[19] Prise, K. M., Schettino, G., Folkard, M. and Held, K. D. 2005. New Insights on Cell Death from Radiation Exposure. The Lancet Oncology. 6(7): 520-528. DOI: https://doi.org/10.1016/S1470-2045(05)70246-1.

[20] Siam, F. M., Grinfeld, M., Bahar, A., Rahman, H. A., Ahmad, H. and Johar, F. 2018. A Mechanistic Model of High Dose Irradiation Damage. Mathematics and Computers in Simulation. 151: 156-168. DOI: https://doi.org/10.1016/j.matcom.2016.02.007.

[21] Hattori, Y., Yokoya, A. and Watanabe, R. 2015. Cellular Automaton-based Model for Radiation-induced Bystander Effects. BMC Systems Biology. 9(1): 90. DOI: https://doi.org/10.1186/s12918-015-0235-2.

[22] Kundrát, P. and Friedland, W. 2012. Non-Linear Response of Cells to Signals Leads to Revised Characteristics of 
Bystander Effects Inferred from Their Modelling. International Journal of Radiation Biology. 88(10): 743-750. DOI: https://doi.org/10.3109/09553002.2012.698029.

[23] Powathil, G. G., Munro, A. J., Chaplain, M. A. and Swat, M. 2016. Bystander Effects and Their Implications for Clinical Radiation Therapy: Insights from Multiscale in silico Experiments. Journal of Theoretical Biology. 401: 1-14. DOI: https://doi.org/10.1016/j.jtbi.2016.04.010.

[24] Olobatuyi, O., de Vries, G. and Hillen, T. 2017. A ReactionDiffusion Model for Radiation-Induced Bystander Effects. Journal of Mathematical Biology. 75(2): 341-372. DOI: https://doi.org/10.1007/s00285-016-1090-5.

[25] McKibben, M. and Webster, M. D. 2014. Differential Equations with MATLAB: Exploration, Applications, and Theory. CRC Press.

[26] Borgonovo, E. and Plischke, E., 2016. Sensitivity Analysis: A Review of Recent Advances. European Journal of Operational Research. 248(3): 869-887.

DOI: https://doi.org/10.1016/j.ejor.2015.06.032.

[27] Zi, Z., Zheng, Y., Rundell, A. E. and Klipp, E. 2008. SBML-SAT: A Systems Biology Markup Language (SBML) Based Sensitivity Analysis Tool. BMC Bioinformatics. 9(1): 342-355. DOI: https://doi.org/10.1186/1471-2105-9-342.

[28] Arthur, J. G., Tran, H. T. and Aston, P. 2017. Feasibility of Parameter Estimation in Hepatitis C Viral Dynamics Models. Journal of Inverse and III-Posed Problems. 25(1): 69-80.

DOI: https://doi.org/10.1515/jiip-2014-0048.

[29] Shirvan, K.M., Mamourian, M., Mirzakhanlari, S. and Ellahi, R. 2017. Numerical Investigation of Heat Exchanger Effectiveness in A Double Pipe Heat Exchanger Filled with Nanofluid: A Sensitivity Analysis by Response Surface Methodology. Powder Technology. 313: 99-111. DOI: https://doi.org/10.1016/j.powtec.2017.02.065

[30] Ingalls, B. 2013. Mathematical Modelling in Systems Biology: An Introduction. MIT Press.

[31] Cooper, G. M. The Cell: A Molecular Approach. 2nd Edition. Sugarland (MA): Sinauer Associate. The Eukaryotic
Cell Cycle., 2000.2 Available from: <https://www.ncbi.nlm.nih.gov/books/NBK9876/>accesse d on June 30, 2018.

[32] Belchior, A., Balásházy, I., Gil, O. M., Vaz, P. and Almeida P. 2014. Does the Number of Irradiated Cells Influence the Spatial Distribution of Bystander Effects? Dose-Response. 12(4): 525-539.

DOI: 001. Belchior.

[33] Li, R. and Mather, J. P. 1997. Lindane, An Inhibitor of Gap Junction Formation, Abolishes Oocyte Directed Follicle Organizing Activity in vitro. Endocrinology. 138(10): 44774480. DOI: https://doi.org/10.1210/endo.138.10.5567.

[34] Bazak, J., Fahey, J. M., Wawak, K., Korytowski, W. and Girotti, A. W. 2017. Enhanced Aggressiveness of Bystander Cells in an Anti-Tumor Photodynamic Therapy Model: Role of Nitric Oxide Produced by Targeted Cells. Free Radical Biology and Medicine. 102: $111-121$. DOI: https://doi.org/10.1016/j.freeradbiomed.2016.11.034.

[35] Han, W., Chen, S., Yu, K. N. and WU, L. 2010. Nitric Oxide Mediated DNA Double Strand Breaks Induced in Proliferating Bystander Cells after $\alpha$-particle Irradiation. Mutation Research/Fundamental and Molecular Mechanisms of Mutagenesis. 684(1): 81-89. DOI: https://doi.org/10.1016/j.mrfmmm.2009.12.004.

[36] Kamran, M. Z., Ranjan, A., Kaur, N., Sur, S. and Tandon, V. 2016. Radioprotective Agents: Strategies and Translational Advances. Medicinal Research Reviews. 36(3): 461-493. DOI: http://dx.doi.org/10.1002\%2Fmed.21386.

[37] Siam, F. M., Kamal, M. H. A. and Johar, F. 2016. Parameter Estimation for a Mechanistic Model of High Dose Irradiation Damage Using Nelder-Mead Simplex Method and Genetic Algorithm. Jurnal Teknologi. 78(12-2): 87-92. DOI: http://dx.doi.org/10.11113/jt.v78.10146. 